\title{
In memoriam prof. dr. Berend Oeseburg (1939-2000)
}

Vlak voor de jaarwisseling is Berend Oeseburg onverwacht overleden. Hij was een opmerkelijke figuur in medisch onderwijskundig Nederland, zowel binnen de faculteiten van Nijmegen (waar hij werkte) en Groningen (waar hij had gewerkt), als binnen de NVMO waar hij lid was van het Algemeen Bestuur. Als bestuurslid van de NVMO etaleerde hij zijn grote betrokkenheid bij de toekomst van de vereniging. Tijdens vergaderingen bracht hij zijn argumenten met een ingetoomde emotionaliteit, die voelbaar was als extra gewicht voor zijn visie op de zaak. Hij ondersteunde van harte de ingeslagen weg om onderwijs meer aandacht en gewicht te geven in de academische wereld.

Hij was altijd duidelijk aanwezig op de NVMO-GOC congressen waar hij, technisch perfect uitgerust met elektronische camera's, de nieuwste computers en printers, rondliep als een ambassadeur van onderwijsvernieuwing in het algemeen en in het bijzonder - uiteraard - van de curriculumvernieuwing te Nijmegen. Opmerkelijk was zijn relatie met studenten op het GOC. Hij coachte de Nijmeegse studentendelegatie aldaar als een ware tutor in de Angelsaksische zin van het woord: zijn studenten op weg helpend in de academische wereld, inhoudelijk tijdens het wetenschappelijke gedeelte overdag, maar ook tijdens de avonduren, wanneer de persoonlijke contacten in informele sfeer worden uitgebouwd.

Berend begon zijn loopbaan in de fysiologie als student-assistent tijdens zijn studie geneeskunde te Groningen. Na het behalen van het artsdiploma gaf hij gehoor aan zijn belangstelling voor het zuurstoftransport via het haemoglobinemolecuul, het onderwerp bij uitstek van de Groningse groep. Zijn liefde voor apparatuur en zijn handigheid in het oplossen van technische problemen maakten hem tot een bekwaam experimentator in de ware zin van het woord. Als docent was hij actief en innovatief op het gebied van de examinering.

$\mathrm{Na}$ het aanvaarden van het hoogleraarschap in de fysiologie te Nijmegen in 1988 vond hij snel zijn plaats in de groep die het nieuwe curriculum aldaar voorbereidde en de invoering ervan begeleidde. Zijn eigen enthousiasme voor integratie, waarin kliniek en prekliniek samen bijdrages leveren aan het onderwijsprogramma, hebben het mede mogelijk gemaakt dat de van nature aanwezige huiver van preklinische disciplines voor dergelijke programma's kon worden weggenomen en omgebogen in een breder beleefd enthousiasme voor de onderwijskundige innovatie.

Zijn persoonlijke leven bleef op de achtergrond in zijn contacten met collegae. Zijn gevoelens en belevingen waren niet altijd makkelijk te kennen. Eenzaamheid moet hij ervaren hebben in de laatste fase van zijn leven, getuige de wijze waarop hij dat leven achter zich heeft gelaten. Nijmegen heeft met respect afscheid genomen van hem in een bijeenkomst waarin Rob Holdrinet in een gevoelvolle rede zijn werk en zijn persoon heeft belicht. Binnen medisch onderwijskundig Nederland zal hij blijven voortleven als een kleurrijke, van de modernste apparatuur voorziene, verschijning die altijd bereid was te bemiddelen en te helpen, maar bovenal als iemand die stond voor zijn zaak.

Herman van Rossum, voorzitter NVMO 